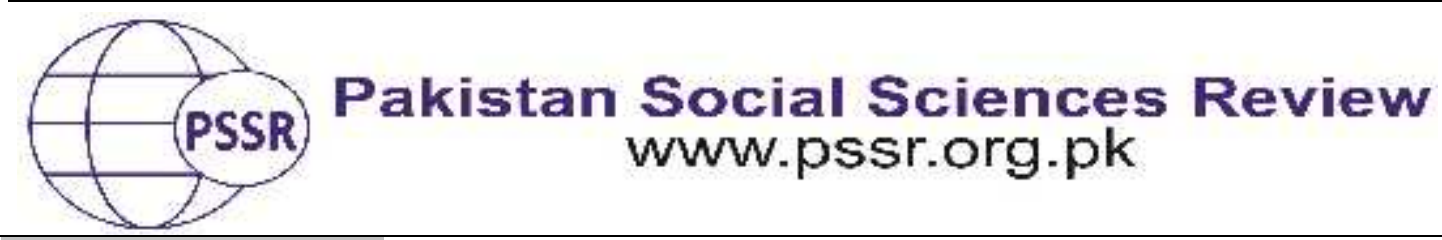

RESEARCH PAPER

\title{
Intellectual Property Promotes Economic Growth: Myth or Reality
}

Ghulam Murtiza ${ }^{1}$ Dr. Qamar Abad 2

1. Assistant Professor, College of Law, Government College University, Faisalabad, Punjab, Pakistan

2. Head KPT Chair, Bahria University, Karachi Campus, Sindh Pakistan

\begin{tabular}{|c|c|}
\hline & \multirow{14}{*}{$\begin{array}{l}\text { ABSTRACT } \\
\text { Intellectual property means the creation of mind. Creations of } \\
\text { mind include names, symbols, inventions, images, artistic and } \\
\text { literary works. There are two forms of intellectual property. First } \\
\text { form is called industrial property and second form is called } \\
\text { copyright. The concept of industrial property covers trademarks, } \\
\text { industrial designs, geographical indications and patents for } \\
\text { inventions. The concept of copyright covers artistic works and } \\
\text { literary works. The artistic works include sculptures, paintings, } \\
\text { architectural design, photographs and drawings. The literary } \\
\text { works include music, films, plays, novels and poems. If the } \\
\text { creations of mind are protected in a society, whether or not this } \\
\text { thing brings prosperity to that society and whether its economic } \\
\text { benefits are innumerable. Finding the answer to this question is } \\
\text { the main purpose of this research. In the context of any } \\
\text { country's economy, it is impossible to deny the importance of } \\
\text { this topic. The study is based on descriptive research and draws } \\
\text { the conclusion that a strong linkage exists between intellectual } \\
\text { property and economic growth. }\end{array}$} \\
\hline & \\
\hline & \\
\hline & \\
\hline & \\
\hline & \\
\hline & \\
\hline & \\
\hline & \\
\hline & \\
\hline & \\
\hline & \\
\hline & \\
\hline & \\
\hline
\end{tabular}

\section{Introduction}

Intellectual property can be expressed as rights in ideas or incorporeal property rights (Harms, 2005). The IPRs are institutional and lawful tools to preserve the concoctions of mind including designs, works of art, inventions and literature etc (Dutfield, 2000).

IP are those legal rights which come into being in result of scholarly action in the literary, technical, artistic and scientific area (Wangwe, 2002). The society awards the intellectual property rights to organizations and individuals for their imaginative works including literary as well as artistic works, inventions, images, names, symbols and designs (Barton, 2002). It can be described as legal based mind creations in concerning which the state gives persons a lawful ownership for a specific period to obstruct their unlawful advantage (Blakeney, 2005). Intellectual property is the identification of conception by the humanistic brain of goods that contains valuation including trade 
secrets, names, industrial designs, computer programs, inventions, books and music (Khalid, 2010). IP contains names, designs, images used in commerce as well as symbols, artistic works, literary works and inventions (Atun, Harvey, \& Wild, 2007). The division of intellectual property rights can be made in two parts: the right to sell and own ideas and after sale, the right to manipulation of those ideas regarding its use (Boldrin \& Levine, 2002).

Whether intellectual property plays a significant role in the economic growth of a country? Whether Intellectual property promotes economic growth or economic growth is hindered by this system? Whether intellectual property rights are critical economic growth determinants? This question has always been in discussion and debate. To answer this question, analyses of different intellectual property experts and economists have been expressed how they have observed the relationship between intellectual property and economic growth.

Horan, Johnson, and Sykes (2005) observe that new products and creative expression is only because of IP system. The insufficient intellectual property protection causes huge losses to industry regarding their investment and reputations.

The role of intellectual property cannot be denied from incentives to innovate. The sustained economic development has changed the lives of millions of people both in developed and developing countries. The higher economic growth is a base of political as well as social changes in a society. The economic growth plays a great role. The economic growth is because of innovation process and IPRs play a significant role to help this process (Greenhalgh \& Rogers, 2010).

If the leaders of the world want economic growth and technology spread, they should re-organize the current IP structure. The IP structure is a gadget for policy designers and when this tool is used correctly, it causes economic growth and innovation (Daley, n.d.). The quick progress of the digital economy creates markets worldwide. However, there is threat as well without enough controls; piracy will cause the spoilage of creative industries (Denton, 2011).

The evils of piracy and counterfeiting are harmful for the economic growth of a country and these can be removed by proper implementation of intellectual property rights (Blakeney, 2004). Innovation is a process from idea to launching a new product in market. The successful innovation can be achieved if intellectual property rights are used properly and perfectly. There is a need of contribution of intellectual property rights in innovation. There is plenty of significance of intellectual property rights in successful business partnerships (Kalanje, 2006).

The statics regarding foreign direct investment and trade indicates that the relative IPRs force of global economic activity is increasing over time (Maskus, 2000a). The IPRs preservation brings innovation and these innovations play an important role in economic growth (Kim, Lee, Park \& Choo, 2012). 
The economists of the world have strong belief that where attention towards intellectual property rights is not properly paid, there would be no economic growth and development (Monsef, Sameti \& Mojahednia, 2011). The spread of scientific knowledge, economic performance and innovation process is only because of intellectual property regime (Ciocoiu, 2011).

In today technological age, the importance of intellectual property rights cannot be denied. Constructing a crucial intellectual property valise is financially significant from offensive as well as defensive point of view (Bastani \& Fernandez, 2005). In current business world, the significance of intellectual property rights cannot be ignored. In today competition world, the intellectual property rights break or make a business (Nivas, 2010).

. The international technology transfer is only because of sound intellectual property rights (Branstetter, Fisman, \& Foley, 2005). The weak preservation restrains investors that believe on intellectual property rights. The weak IP dynasty inspires investors to enter upon the business of distribution instead of local production (Javorcik, 2004). Kyle and McGahan (2012) find that implementation of patent preservation increases profits from drug development. Maskus and Penubarti (1995) examine that in both small and large developing economies, greater patent protection plays a positive role in increasing bilateral manufacturing imports.

As economic point of view, IPRs have gained a lot of significance. Patents, copyrights, trademarks, industrial designs, geographical indications, integrated circuits are repeatedly mentioned in debates as well as discussions on topics like education, food security, public health, industrial policy, trade, traditional knowledge, the internet, biotechnology, biodiversity, media industries and the entertainment. In a knowledge based economy, an understanding of intellectual property rights is essential for informed policy making in all human development areas (Muskus, 2004).

There has been a voice regarding intellectual property rights safety with the expansion of international transactions concerning knowledge intensive products, encouraging demands for international union toward greater standards of care at a worldwide level (Braga \& Fink, 1996). The relationship of IPRs and FDI cannot be ignored. Where there would be greater protection of IPRS, definitely there would be greater foreign direct investment (Braga \& Fink, 1998). The safety of intellectual property rights is a strong source of inward investment and in presence of other economic policy variables; IPRs have a greater affect on inward investment (Seyoum, 1996).

The powerful patent preservation framework is an effective source of research and development passion (Varsakelis, 2001). Each kind of intellectual property involves investment in intellectual effort or in case of trademarks, the investment in reputation. The competitors can easily copy or imitate these intangible investments. The persons who do not play any role to the original IP investment, without protection of IPR, it is really very difficult to prevent free riding by these persons (Revesz, 1999). 
The effect of unwarranted use of intellectual property is greater on international environment for innovation, technology transfer and economic development (Mansfield, 1993). The rich countries take advantages from domestic technology as well as foreign technology whereas middle income nations take advantages from foreign technology and imported major products. As far as poor nations are concerned, they benefit largely from foreign technology. The foreign patents deluge in middle and low income nations are mainly affected by government policies on IPRs protection (Xu \& Chiang, 2005).

Those countries that have stronger patent rights attract greater arm's length volumes of licensed technology (Yang \& Maskus, 2001). The stronger IPRs have a definite and persuasive affect on backward knowledge diffusion from multinational firms (Smeets \& de Vaal, 2011). The strengthening intellectual property rights has become an unavoidable custom in order to attract foreign direct investment, high technology and ultimately to achieve economic growth (You \& Katayama, 2003). The intellectual property rights play a sound role in stimulating FDI and technology transference (Maskus, 1998a).

IPRs help in stimulating the least developed nations' economic growth (Homere, 2003). The sound IP rights, if properly structured can enhance economic growth and encourage technological development (Maskus, 2001). The economic development and technology transfer is only because of strong preservation of intellectual property rights (Schiappacasse, 2003). The influence of IP regimes on foreign investments in developing nations is greater (Hindman, 2005). The protection of intellectual property is critical for full-fledged technology transfer (Sherwood, 2002).

Once a particular level of development has been achieved, the stronger patent protection increases economic development rates (Thompson \& Rushing, 1996). The stronger intellectual property rights safety that decreases the duplication possibility enhances the premium for novelty (Horii \& Iwaisako, 2007). The investors are very well aware of intellectual property rights systems in individual countries and act carefully. Countries that want to strengthen their economic activities, they should protect their IPR systems accordingly (Lesser, 2001).

Today in many countries, obstacles are there in obtaining legal and formal property rights. The property rights play a major task in the development course. The citizens of those countries tend to grow faster that have secure and legal property rights in comparison to countries with weaker property rights (Lewer \& Saenz, 2011). Copyrights industries are significant contributors to the industrialized countries economies. The significance of copyright works regarding economic terms is increasingly dramatically (Picard \& Toivonen, 2004).

The major developed nations provide sound mechanism of patent preservation. But this safety is influenced by many factors including standard of research and development in the country, international unification and market situation (Ginarte \& Park, 1997). 
Less developed countries desirous of receiving foreign direct investment should provide greater patent protection. The stronger patent protection is one of the significant characteristics of an attractive investment climate (Kondo, 1995). The patent protection is a strong determinant of investment flows. This relationship helps firms and governments to devise appropriate intellectual property policy to encourage the growth and expansion of foreign direct investment (Seyoum, 2006).

The improved IP protection laws and their sound implementation are likely to translate into considerably greater inflows of FDI (Mansfield, 1995). To manage the powerful forces of market globalization as well as technological change, the establishment of legal institutions is very essential. To meet this challenge, international reform of IPRs plays an important role which provides the basis for building and extending markets for new technologies (Maskus, 2000c). The strong link exists among preservation of IPRs, economic development, innovation, and technology diffusion (Anja \& Neil, 2012).

The relationship cannot be ignored among important policy issues such as corporate governance, FDI, innovation readiness, IPRs, e-commerce, skill training, and supply management (Luthria \& Nabi, 2002). Intellectual property protection is significant for developing economies because it helps in creation of new knowledge as well as deep sharing of knowledge and promotes economic growth. Economic growth is through creation of new enterprise, transfer of innovations, increased FDI and lowering transaction costs in trade. The advantages of intellectual property protection can be enhanced through such environment that promotes economic growth. Developing economies can get the advantages of IP preservations through policies, competitive practices and enhance the capability to utilize intellectual property protection (Alfarraj, 2016).

TRIPS has broader impact on foreign direct investments, technology flows, as well as on local innovation (Correa, 1997). Today the developing countries are facing the challenge of enforcing various international agreement negotiated during the Uruguay Round. In this process, they are becoming aware of many implications for their development, economies and societies inherent in some of these agreements. TRIPS Agreement is a case in point. Its enforcement is emerging as a major concern for all developing countries. The intention of preparing this document was to assist the developing nations in their struggle to comply their laws with the levels set by TRIPS regarding pharmaceutical products and processes. Such legislative reform has major effect on people's access to drugs and public health policies (Correa, 2000).

Enhancement in intellectual property protection generate research and development activity sound to compensate the societal value of the restricted ownership allowed to holders of copyright, patentees and other partners of intellectual property (Siebeck, Evenson, Lesser \& Braga, 1990).

The stronger intellectual property rights preservation keeps multinationals from imitation (Glass \& Saggi, 2002). The greater intellectual property protection may help 
attract high quality FDI (Nunnenkamp \& Spatz, 2004). IPRs system is changing deeply. Many developing countries have significantly strengthened their intellectual property regimes. Many regional trading arrangements now talk about the questions of regulatory convergence, especially in the area of IPRs. Most significant is the addition of the TRIPS within WTO. Under TRIPS, WTO representatives are under obligation to adopt and implement TRIPS. The developed countries are extending greater safety to controversial area including electronic database and biotechnology. The motion toward much greater global intellectual property rights is consistent with processes of economic globalization (Maskus, 2002). The private property rights' affect on economic development is positive and at the time determined (Heitger, 2003).

In today global economy, economic prosperity does not come from natural resources or the production of industrial goods. It comes from new ideas and new products. In fact, the differences between poor and rich countries in terms of science, technology and knowledge are more important today rather than differences in income. The developed states own approximately $99 \%$ of the stock of patents registered in U.S.A and Europe. TRIPS agreement privileged the position of developed countries and further increases the wealth gap between those who own IPRs and those who wish to use them (May, 2013). In such atmosphere, where patent preservation is doubtful, transference of technology will remain a dream and there would be a greater risk for pioneer firm (Vishwasrao, 1994). The patent protection system of a host country influences the mode of technology transfer which in turn affects the welfare of the recipient country (Fosfuri, 2000). There is strong link of IPRs to trade system, research \& development, global development and collective welfare methods (Taylor, 1994). The patent system is one of the most powerful policy instruments that have been used for the diffusion and development of new technologies (Watanabe, 1985). The economies whether developed or developing are taking advantage of copyright. According to a survey, 5 per cent of GDP comes from copyright industries and this figure is increasing with the passage of time (Watt, 2009). Transfer of technology from the more to the less advanced countries has been a central source of economic development throughout human history and this is possible only because of protection of intellectual property rights (Chang, 2001).

The upgraded preservation of intellectual property rights has significant affect on foreign direct investment geographical choices, though the level of protection varies with the characteristics of host and home countries. There is a large and important role for host as well as home country authorities to play in making intellectual property policies to affect foreign direct investment (Zhang, 2007).

The influence of IPRs on innovations in developing nations is positive and there is U-shaped linkage between IP rights and economic development (Chen \& Puttitanun, 2005). IPRs perform a major function in improving scientific novelty and in technology transference and distribution in such a way which is helpful for socio-economic prosperity (Léger, 2006). The acceptance of greater patent laws and composition of patent rights differ across countries by degree of economic development (Park, 2008). 
The stronger patents attract more innovation (Sakakibara \& Branstetter, 2001). The research and development is not prevented by patents or licensing. Actually they both improve research and development. This worldwide concept applies equally both to developed and developing nations (Price, 1991). In the field of globalization, in economic activity, knowledge and innovation play an important role. In literature of economic growth, the preservation of IPRs has therefore achieved a significant place because it motivates technological change that is essential for economic growth (Adams, 2011). The intercommunication between IPRs and the rate and direction of technological change has been a rich ground for policy debate and economic analysis. It has long been determined that intellectual property rights supplement with monopoly right it grants to its holders is an essential compromise that society has to endure for ensuring investors in new inventive and creative works of the profitability of these creations (Hu \& Jaffe, 2007).

The strength of IP preservation has a strong positive influence on innovation (Kanwar, 2006). The safety of intellectual property has been on the forefront of developments in most developed and developing countries. Any country with the desire of economic growth must pay attention to safety and implementation of intellectual property rights. The foreign direct investment comes into a country when an investor knows that there is return on investment and this can be achieved mostly with preservation of intellectual property rights and effective implementation. Through intellectual property rights growth and safety, any country can explore huge investment opportunities. This will result in increased revenue. Comparatively, non protection of intellectual property rights will compel investors to take their businesses to other jurisdictions. It will cause the loss of jobs and government revenue through non-payment of taxes (Nwokocha, 2008).

In a country's economic growth, IPRs perform significant functions. The standardized IP preservation creates a useful influence on the development ratio of a country. This connection between IPRs and economic development is non linear. The economic growth is high if the level of protection is high (Lindroos, 2015). IP is a powerful device for wealth creation and economic development. Information, creativity, inventiveness and knowledge are driving forces of economic growth and social well being (Idris, 2003).

A significant role is played by IPRs in economic development of a country. In the area of agriculture, IP policies affect the lives of millions of farmers (Braga, Fink \& Sepulveda, 2000). IP is essential for a developing country's development policy (Blakeney, 2005). A strong link exists between IP and socio-economic development of a country (Olwan, 2011). The effective system of intellectual property rights promotes economic development (Maskus, 2000b). It is not possible to separate intellectual property rights and its impact on general strength of institutions (Popov, 2011).

The property rights both tangible and intangible are fundamental for economic success. There is need of stronger intellectual property protection for sound economic development and income gains (Keating, 2006). Those countries find great incentives 
that use the flexibilities in the TRIPS Agreement for their development. Unlimited benefits in terms of technology transfer and growth especially for developing countries are there if strict intellectual property protection is observed. There is a greater link among IPRs preservation, economic development and technology spread (Falvey, Foster \& Memedovic, 2006).

IP protection strengthens trade opportunities for all nations and help in increasing access of developing nations to the new technology essential for their development (Mossinghoff, 1984).

Intellectual property rights apply similar effects as rule of law and therefore provide strong evidence that physical as well as intellectual property rights are critical development determinants. The unenforced intellectual property rights play no effective role on development (Eicher \& Newiak, 2013).

\section{Conclusion}

Analyses of different authors have been expressed how they have observed the connection between IP and economic growth. In their opinion, intellectual property benefits the economy. Both in developed and developing countries, it promotes technology transfer and foreign direct investment. Intellectual property promotes innovation. Effective intellectual property enhances funding for R\&D. Its protection helps firms in creating their innovation and grows. The firms that use intellectual property rights have a higher market value and succeed better. The sectors that rely on patent play an important role in the overall economy. In developed and developing nations, IPRs create strong economic activity and development. In developing nations, firms as well as inventors want to protect their inventions by patents. The people strongly rely on trademark system to protect their brands abroad and at home. For overall health of economy, intellectual property is an important part. The poor protection of IPR causes piracy and counterfeiting that badly damages the economic benefits of IPR. 


\section{References}

Adams, S. (2011). Intellectual property rights, innovation, and economic growth in SubSaharan Africa. Journal of Third World Studies, 28(1), 231.

Alfarraj, A. (2016). Intellectual Property Protection in Emerging Economies and Trade Related Intellectual Property Rights.

Anja, B., \& Neil, F. (2012). Intellectual property rights, innovation and technology transfer: a survey.

Atun, R. A., Harvey, I., \& Wild, J. (2007). Innovation, patents and economic growth. International Journal of Innovation Management, 11(02), 279-297.

Barton, J. H. (2002). Integrating intellectual property rights and development policy: Report of the commission on intellectual property rights: Commission on Intellectual Property Rights.

Bastani, B., \& Fernandez, D. (2005). Intellectual property rights in nanotechnology. Inform. Technol. J, 4, 69-74.

Blakeney, M. (2004). Enforcement of intellectual property rights: Challenges, Remedies, and Public awareness. World Intellectual Property Organization,(accessed March 29, 2017),[available at http://www. wipo. int/edocs/mdocs/arab/en/wipo_ ip_uni_dub_04/wipo_ip_uni_dub_04_7.doc].

Blakeney, M. (2005). Guidebook on Enforcement of Intellectual Property Rights. Queen Mary Intellectual Property Research Institute.

Boldrin, M., \& Levine, D. K. (2002). The case against intellectual property. The American Economic Review, 92(2), 209-212.

Braga, C. A. P., \& Fink, C. (1996). The Economic Justification for the Grant of Intellectuall Property Rights: Patterns of Convergence and Conflict. Chi.-Kent L. Rev., 72, 439.

Braga, C. A. P., \& Fink, C. (1998). The relationship between intellectual property rights and foreign direct investment. Duke J. Comp. E Int'l L., 9, 163.

Braga, C. A. P., Fink, C., \& Sepulveda, C. P. (2000). Intellectual Property Rights and Economic Development (Vol. 412): World Bank Publications.

Branstetter, L., Fisman, R., \& Foley, C. F. (2005). Do stronger intellectual property rights increase international technology transfer? Empirical evidence from US firm-level data. The Quarterly Journal of Economics, 121(1), 321-349. 
Chang, H.-J. (2001). Technology transfer, intellectual property rights and industrial development in developing countries. Cambridge, background paper prepared for UNIDO.

Chen, Y., \& Puttitanun, T. (2005). Intellectual property rights and innovation in developing countries. Journal of development economics, 78(2), 474-493.

Ciocoiu, C. N. (2011). Considerations about Intellectual Property Rights, Innovation and Economic Growth in the Digital Economy. Economia. Seria Management, 14(2), 310323.

Correa, C. M. (1997). New intellectual standards for intellectual property: Impact on technology flows and innovation in developing countries. Science and Public Policy, 24(2), 79-92.

Correa, C. M. (2000). Integrating public health concerns into patent legislation in developing countries: South Centre Geneva.

Daley, W. (n.d.). In search of Optimality: Innovation, Economic Development, and Intellectual Property Rights.

Denton, A. (2011). Intellectual Property Rights in Today's Digital Economy. Retrieved from GSR 11 Discussion Paper

Dutfield, G. (2000). Literature survey on intellectual property rights and sustainable human development.

Eicher, T. S., \& Newiak, M. (2013). Intellectual property rights as development determinants. Canadian Journal of Economics/Revue canadienne d'économique, 46(1), 422.

Falvey, R. E., Foster, N., \& Memedovic, O. (2006). The role of intellectual property rights in technology transfer and economic growth: theory and evidence: UNIDO.

Fosfuri, A. (2000). Patent protection, imitation and the mode of technology transfer. International Journal of Industrial Organization, 18(7), 1129-1149.

Ginarte, J. C., \& Park, W. G. (1997). Determinants of patent rights: A cross-national study. Research Policy, 26(3), 283-301.

Glass, A. J., \& Saggi, K. (2002). Intellectual property rights and foreign direct investment. Journal of International economics, 56(2), 387-410.

Greenhalgh, C., \& Rogers, M. (2010). Innovation, intellectual property, and economic growth: Princeton University Press. 
Harms, L. T. (2005). The enforcement of intellectual property rights: a case book: World Intellectual Property.

Heitger, B. (2003). Property rights and their impact on the wealth of nations: a cross-country study.

Hindman, D. (2005). The Effect of Intellectual Property Regimes on Foreign Investments in Developing Economies. Ariz. J. Int'l E Comp. L., 23, 467.

Homere, J. R. (2003). Intellectual property rights can help stimulate the economic development of least developed countries. Colum. JL $\mathcal{E}$ Arts, 27, 277.

Horan, A., Johnson, C., \& Sykes, H. (2005). Foreign infringement of intellectual property rights: Implications for selected US industries. Retrieved from (No. 15883). United States International Trade Commission, Office of Industries

Horii, R., \& Iwaisako, T. (2007). Economic growth with imperfect protection of intellectual property rights. Journal of Economics, 90(1), 45-85.

Hu, A. G. Z., \& Jaffe, A. B. (2007). IPR, innovation, economic growth and development. Department of Economics, National University of Singapore.

Idris, K. (2003). Intellectual property: a power tool for economic growth (Vol. 888): WIPO.

Javorcik, B. S. (2004). The composition of foreign direct investment and protection of intellectual property rights: Evidence from transition economies. European economic review, 48(1), 39-62.

Kalanje, C. M. (2006). Role of intellectual property in innovation and new product development. World Intellectual Property Organization.

Kanwar, S. (2006). Innovation and intellectual property rights. Center for development economics working paper(142).

Keating, R. J. (2006). Importance of Intellectual Property in the International Marketplace. Small Business and Entrepreneurship Council, Washington, June.

Khalid, A. R. (2010). The Economic Contribution of Copyright-Based Industries in

Pakistan. Found on 07-04-2017 from http://www.wipo.int/export/sites/www/copyright/en/performance/pdf/econ_ contribution_cr_pk.pdfEndeshaw, A. (2013). Intellectual Property in Asian Emerging Economies: Law and Policy in the Post-TRIPS Era. Farnham: Ashgate

Khan, B. Z. (2005). The Democratization of Invention: patents and copyrights in American economic development, 1790-1920: Cambridge University Press. 
Kim, Y. K., Lee, K., Park, W. G., \& Choo, K. (2012). Appropriate intellectual property protection and economic growth in countries at different levels of development. Research Policy, 41(2), 358-375.

Kondo, E. K. (1995). The Effect of Patent Protection on Foreign Direct Investment, The. Journal of World Trade, 29(6), 97-122.

Kyle, M. K., \& McGahan, A. M. (2012). Investments in pharmaceuticals before and after TRIPS. Review of Economics and Statistics, 94(4), 1157-1172.

Léger, A. (2006). Intellectual property rights and innovation in developing countries: evidence from panel data. Paper presented at the Proceedings of the German Development Economics Conference, Berlin.

Lesser, W. (2001). The effects of TRIPS-mandated intellectual property rights on economic activities in developing countries. World Intellectual Property (WIPO) Studies, 1, 1-24.

Lewer, J. J., \& Saenz, M. (2011). Property rights and economic growth: Panel data evidence. Southwestern Economic Review, 32, 157-166.

Lindroos, J. (2015). Intellectual property rights and economic growth.

Luthria, M., \& Nabi, I. (2002). Protecting Intellectual Property: Why, How Much, How? Building Competitive Firms, 165.

Mansfield, E. (1993). Unauthorized use of intellectual property: effects on investment, technology transfer, and innovation. Global Dimensions of Intellectual Property Rights in Science and Technology, 107.

Mansfield, E. (1995). Intellectual property protection, direct investment, and technology transfer: Germany, Japan, and the United States (Vol. 27): World Bank Publications.

Maskus, K. E. (1998a). The role of intellectual property rights in encouraging foreign direct investment and technology transfer. Duke J. Comp. \& Int'l L., 9, 109.

Maskus, K. E. (2000a). The economics of intellectual property rights and globalization: Dancing the dual distortion. Intellectual Property Rights in the Global Economy, 1-89.

Maskus, K. E. (2000b). Intellectual property rights and economic development. Case W. Res. J. Int'l L., 32, 471.

Maskus, K. E. (2000c). Intellectual property rights in the global economy: Peterson Institute.

Maskus, K. E. (2001). Intellectual property challenges for developing countries: An economic perspective. U. Ill. L. Rev., 457. 
Maskus, K. E. (2002). 12 IPRs and FDI. Foreign Direct Investment: Research Issues, 22, 195.

Maskus, K. E. (2004). Encouraging international technology transfer (Vol. 7): International Centre for Trade and Sustainable Development Geneva.

Maskus, K. E., \& Penubarti, M. (1995). How trade-related are intellectual property rights? Journal of International economics, 39(3), 227-248.

May, C. (2013). The global political economy of intellectual property rights: The new enclosures? (Vol. 3): Routledge.

Monsef, A., Sameti, M., \& Mojahednia, M. (2011). The Effect of Intellectual Property Rights and Information and Communication Technology on Human Development Index in Developing Countries During 2005-2010. Australian Journal of Business and Management Research, 1(9), 105.

Mossinghoff, G. J. (1984). The importance of intellectual property protection in international trade. BC Int'l \& Comp. L. Rev., 7, 235.

Nivas, S. (2010). IP RIGHTS AND DIGITIZED CONTENT. Indian Journal of Computer Science and Engineering, 1(2), 977-980.

Nwokocha, U. (2008). Nigeria Intellectual Property: Overview of Development and Practice: Ibadan, Ibadan University Press.

Olwan, R. M. (2011). Intellectual property and development: theory and practice. Queensland University of Technology.

Park, W. G. (2008). International patent protection: 1960-2005. Research Policy, 37(4), 761766.

Picard, R., \& Toivonen, T. (2004). Issues in assessment of the economic impact of copyright. Review of Economic Research on Copyright Issues, 1(1), 27-40.

Popov, V. (2011). Do we need to protect intellectual property rights?

Price, S. C. (1991). The economic impact of novel genes in plant biotechnology: Not without strong intellectual property rights. Conservation of Plant Genes: DNA banking and in vitro biotechnology. R. P. Adams and J. E. Adams. San Diego E London, Academic Press.

Revesz, J. (1999). Trade-related aspects of intellectual property rights: Citeseer.

Sakakibara, M., \& Branstetter, L. (2001). Do stronger patents induce more innovation? Evidence from the 1988 Japanese patent law reforms. Rand Journal of Economics, 32(1), 77-100. 
Schiappacasse, M. (2003). Intellectual property rights in China: technology transfers and economic development. Buff. Intell. Pro. LJ, 2, 164.

Seyoum, B. (1996). The impact of intellectual property rights on foreign direct investment. The Columbia Journal of World Business, 31(1), 50-59.

Seyoum, B. (2006). Patent protection and foreign direct investment. Thunderbird International Business Review, 48(3), 389-404.

Sherwood, R. M. (2002). Global prospects for the role of intellectual property in technology transfer. IDEA, 42, 27.

Siebeck, W., Evenson, R. E., Lesser, W., \& Braga, C. A. P. (1990). Strengthening Protection of Intellectual Property in Developing Countries. World Bank Discussion Papers, 112.

Smeets, R., \& de Vaal, A. (2011). Intellectual property rights protection and FDI knowledge diffusion. VOXEU (March 15). http://www. voxeu. org/article/intellectualproperty-rights-and-fdi-knowledge-diffusion.

Taylor, M. S. (1994). TRIPS, trade, and growth. International Economic Review, 35(2), 361381.

Thompson, M. A., \& Rushing, F. W. (1996). An empirical analysis of the impact of patent protection on economic growth. Journal of Economic Development, 21(2), 61-79.

Varsakelis, N. C. (2001). The impact of patent protection, economy openness and national culture on R\&D investment: a cross-country empirical investigation. Research Policy, 30(7), 1059-1068.

Vishwasrao, S. (1994). Intellectual property rights and the mode of technology transfer. Journal of development economics, 44(2), 381-402.

Wangwe, S. (2002). Country case study for Study 9: Institutional issues for developing countries in IP policy-making, administration and enforcement: Report commissioned by the Commission on Intellectual Property Rights.

Watanabe, S. (1985). The Patent System and Indigenous Technology Development in the Third World'. Technology, Institutions, and Government Policies, Macmillan, London, 217-257.

Watt, R. (2009). An empirical analysis of the economics of copyright: how valid are the results of studies in developed countries for developing countries? The Economics of Intellectual Property, 65.

Xu, B., \& Chiang, E. P. (2005). Trade, patents and international technology diffusion. The Journal of International Trade \& Economic Development, 14(1), 115-135. 
Yang, G., \& Maskus, K. E. (2001). Intellectual property rights and licensing: An econometric investigation. Review of World Economics, 137(1), 58-79.

You, K., \& Katayama, S. (2003). Is the IPRs Protection working effectively in Developing countries?

Zhang, A. (2007). The impacts of home and host country's intellectual property rights protection on foreign direct investment. City University of Hong Kong. 